\title{
Fast pyrolysis and steam gasification of pellets prepared from olive oil mill residues
}

\author{
M. Lajili ${ }^{\text {a }}$, C. Guizani ${ }^{\text {b }}$, F.J. Escudero Sanz ${ }^{\text {b }}$, M. Jeguirim ${ }^{\text {c, * }}$ \\ a Université de Monastir, Unité de Recherche Etude des Milieux Ionisés et Réactifs (EMIR), IPEIM, Avenue Ibn Eljazzar Monastir, 5019, Tunisia \\ ${ }^{\mathrm{b}}$ Laboratoire RAPSODEE, Mines Albi Route de Teillet, 81013 Albi CT Cedex 09, Albi France \\ ${ }^{\mathrm{c}}$ Institut de Science des Matériaux de Mulhouse, 3 Bis Rue Alfred Werner, 68093 Mulhouse, France
}

Keywords:

Olive oil mill residues

Agro-pellets

Impregnation

Fast pyrolysis

Gasification

\section{A B S T R A C T}

This paper examines the fast pyrolysis coupled with the steam gasification of agropellets prepared from the olive oil industries by-products via Macro-thermogravimetry. Three pellets samples were prepared from exhausted olive mill solid waste, impregnated olive mill wastewater/exhausted olive mill solid waste and impregnated olive mill wastewater/pine sawdust. The behavior of the three pellets during the fast pyrolysis and the char gasification stages were generally comparable despite some small differences in the conversion rates or char yields. The gasification of impregnated olive mill wastewater/exhausted olive mill solid waste pellets was selected as a promising route for their valorization and the reduction of the pollution impacts of olive mill wastewater. The impregnated olive mill wastewater/exhausted olive mill solid waste pellets pyrolysis rate was affected significantly by the temperature in the range of $750^{\circ} \mathrm{C}$ $-950^{\circ} \mathrm{C}$. The mean char gasification rate was linearly dependent on temperature and steam molar fractions in the respective ranges of $750^{\circ} \mathrm{C}-950^{\circ} \mathrm{C}$ and $10 \%-30 \%$ of steam concentration. The provided data on the fast pyrolysis and char gasification of the formulated impregnated olive mill wastewater/ exhausted olive mill solid waste pellets constitute new set of experimental data that can serve for the design of gasifiers working with such kind of wastes.

\section{Introduction}

The energy supply represents a major challenge facing our planet today. In particular, the switch from fossil resources into sustainable and renewable ones becomes an absolute necessity. Indeed, this transition is motivated by the recognized effect of greenhouse gas and other pollutants emissions on human health and climate change [1]. Among the various renewable resources, biomass feedstock has received particular attention due to their high availability worldwide [2]. Furthermore, biomass can be converted into energy or biofuels via different thermochemical processes including torrefaction/carbonization, pyrolysis, combustion and gasification [3-6].

Currently, biomass combustion is the thermochemical conversion process that is technologically advanced at large scale. In fact, electricity and district heating production from biomass is widely developed. It is based generally on grate-firing technologies such as

\footnotetext{
* Corresponding author.

E-mail address: mejdi.jeguirim@uha.fr (M. Jeguirim).
}

boilers, fixed and fluidized beds. These plants are sophisticated with the implementation of flue gas cleaning systems, to improve their efficiency, and also to mitigate the pollutant effect of gaseous emissions. Nevertheless, in spite of this technological progress, many problems related to mineral contents are still embarrassing. Indeed, the corrosion and the slag formation and the bottom ash agglomeration are influencing negatively the combustion efficiency and the boilers lifetime [7,8]. Therefore, the other conversion processes should be developed in order to recover biomass with high mineral contents such as agriculture and food processing residues.

During the last decade, pyrolysis and gasification emerged as suitable paths for producing alternative solid, liquid and gaseous biofuels. Especially, alternative gaseous biofuels can be obtained through biomass gasification under water vapor and/or carbon dioxide $[9,10]$. Investigations on biomass gasification show that syngas composition, depending on the gasification agents, includes $\mathrm{H}_{2}, \mathrm{CO}, \mathrm{CO}_{2}, \mathrm{CH}_{4}, \mathrm{~N}_{2}, \mathrm{H}_{2} \mathrm{O}$ and small amounts of tar. The gas concentration depends not only on the used technology and thermodynamic variables, but also on the biomass nature and the gasifier agent [11]. The $\mathrm{H}_{2}$ and $\mathrm{CO}$ are the major interesting gas in the syngas composition since they could be converted to alternative 
synthetic biofuel through various processes such as Fischer-Tropsch reaction [12].

Pyro-gasification is a promising thermochemical conversion process for syngas production and particularly for hydrogen production when vapor steam is used as gasification agent. This technique could be described as a combination between pyrolysis followed by gasification. Indeed, upon heating the biomass gets dry up to $120^{\circ} \mathrm{C}$, then a devolatilisation phase of volatile organic compounds occurs up to $500^{\circ} \mathrm{C}$ leaving the remained residual char [13]. Afterwards, the char can be gasified at a temperature higher than $750^{\circ} \mathrm{C}$ using a gasifier agent.

Several investigations have examined the char gasification under different atmospheres [13-18]. These investigations have shown clearly that the operating condition such as temperature and gasification agent composition and concentration influence strongly the syngas composition. In addition, the biomass physicochemical properties seem to affect strongly the gasification reactivity. Indeed, minerals such as $\mathrm{Na}, \mathrm{K}$ and $\mathrm{Mg}$ may catalyze the gasification reaction while others such as $\mathrm{Si}, \mathrm{P}$ and $\mathrm{Al}$ have an inhibiting effect $[13,17,18]$. Furthermore, char textural and structural properties are clearly correlated to gasification rate [17].

In the Mediterranean region, olive mills produce huge amounts of olive mill wastewater (OMWW) and olive mill solid waste (OMSW). The olive mill solid waste is a mixture of olive pomace and olive seeds. In Tunisia, 1525 olive-oil manufacturers use the three phases' extraction system for the olive oil production. Their average annual production of olive oil is 210.000 tons generating 1.3 million $\mathrm{m}^{3}$ of OMWW and about 550.000 tons of OMSW. The recovery of these wastes represents a major challenge. Several investigations were performed in order to identify the suitable strategy for the recovery of these wastes. Jeguirim et al. [19] have proposed the impregnation of olive mill waste water (OMWW) on dry biomasses including pine sawdust (PS) and (OMSW). Authors found that the mineral contents present in the OMWW accelerate the thermal degradation of dry biomasses. Kraeim et al. [20] and Lajili et al. $[21,22]$ pursued this investigation through pellets production and combustion in a domestic boiler. Authors have found a higher boiler and combustion efficiencies in agreement with the requirements of European standards. However, an increase in particulate matter (PM) emissions and residual ash content may limit their application in domestic and industrial boilers. Therefore, it seems necessary to examine their recovery through fast pyrolysis and gasification techniques.

In this context, the reactivity of these prepared pellets under pyro-gasification conditions is examined in this present work. In particular, the global reactivity of the samples, by calculating the conversion, the rate of conversion and the char reactivity, during the pyrolysis and the gasification phases, is examined. Furthermore, a particular attention is paid to the effect of operation conditions such as temperature and water vapor concentration. The obtained data during this work and the future kinetic study with the gasification yields analysis will be of a great help for the design of gasifiers fed with pellets based on olive oil residues.

\section{Materials and methods}

\subsection{Pellets production and characterization}

OMWW and exhausted olive mill solid waste (EOMSW) used in this study were collected from three-phase centrifugal olive mill located in Mahdia, Tunisia. It is to be highlighted that the EOMSW is obtained from OMSW after the second extraction of the (3-5\%) of residual oil. Sawdust was provided from sawmill located in Sayada, Tunisia. The mixtures of non-impregnated samples were dried under sun then intimately mixed using hands in order to minimize their heterogeneity. During impregnation tests, $20 \mathrm{~kg}$ of EOMSW or sawdust were slowly added to $100 \mathrm{~kg}$ of OMWW while continuously agitating the mixture in a specific basin. Then, the impregnated samples were dried naturally under sun until reaching moisture content lower than $15 \%$.

Three different agropellets were prepared through the densification in order to obtain:

- Exhausted Olive Mill Solid Waste (EOMSW),

- Impregnated Exhausted Olive Mill Solid Waste (IEOMSW) prepared from the impregnation of the olive mill wastewater on exhausted olive mill solid waste.

- Impregnated pine sawdust (IPS) prepared from the impregnation of olive mill wastewater on pine sawdust

The densification of these different pellets was carried out exactly as we realized in our previous work [20]. Indeed, a pelletizer KAHL 15/75 type (Amandus Kahl GmbH \& Co, Reinbek, Germany) containing a die diameter of $6 \mathrm{~mm}$ and a length of $30 \mathrm{~mm}$ was used. the obtained pellets are cylindrical with $15-30 \mathrm{~mm}$ of length and $5-6 \mathrm{~mm}$ diameter. The mass of each pellet varies between 2.5 and $3 \mathrm{~g}$ depending on the type of samples.

Specifications of the used pelletizer are: Die diameter $(\mathrm{mm})$ : 175 , Diameter/length of roller $(\mathrm{mm}): 130 / 29$, Number of rollers: 2 , Control motor $\left(\mathrm{kW} / \mathrm{min}^{-1}\right)$ : 3 , Roller speed $(\mathrm{m} / \mathrm{s})$ : $0.5-0.8$. The capacity of the pelletizer depend was about $2-3 \mathrm{~kg} / \mathrm{h}$.

The characteristics of pellets were determined using different analytical techniques based on the available European standards. Moisture and ash contents were achieved by following EN 14774-2 and EN 14775 standards respectively. Nitrogen (N) determination was carried out according to EN 15104 by means of a CHONS elemental analyser. Sulphur $(\mathrm{S})$ and chlorine $(\mathrm{Cl})$ contents were determined following EN 15289. The major inorganic elements analysis of the produced pellets was performed according to EN 15290 using an inductively coupled plasma atomic emission spectroscopy (ICP-AES). The minor elements analysis was performed according to NF EN ISO 16968.

The high heating value (HHV) was determined using an adiabatic oxygen bomb calorimeter (IKA C200). LHV is calculated from HHV by taking into account the thermal heat losses due to water vaporization. The values corresponding to low heating values (LHV), bulk density (BD) and energy density (ED) are considered to represent the energetic characteristics of the different studied biomasses.

Concerning the porosity of the samples, it can be calculated using the following expressions:

$p=1-\frac{\rho_{b}}{\rho_{u}}$

Where, $\mathrm{p}$ is the porosity, $\rho_{b}$ and $\rho_{u}$ are respectively the bulk density and the unit density.

\subsection{The M-TG experimental apparatus}

The steam gasification of the agro-pellets is assessed using a Macro-Thermogravimetric reactor (M-TG) which is meticulously described in Ref. [23].

Grossly, the Macro-Thermogravimetric reactor (M-TG) includes three parts: (1) a heating system including a liquid water evaporator, a gas pre-heater and a cylindrical alumina reactor which are heated electrically, (2) a gas flow control system using mass flow meters/controllers, (3) a weighing system comprising an electronic scale and a stand with a platinum basket.

The alumina reactor, which is $2 \mathrm{~m}$ long and $0.75 \mathrm{~m}$ internal 


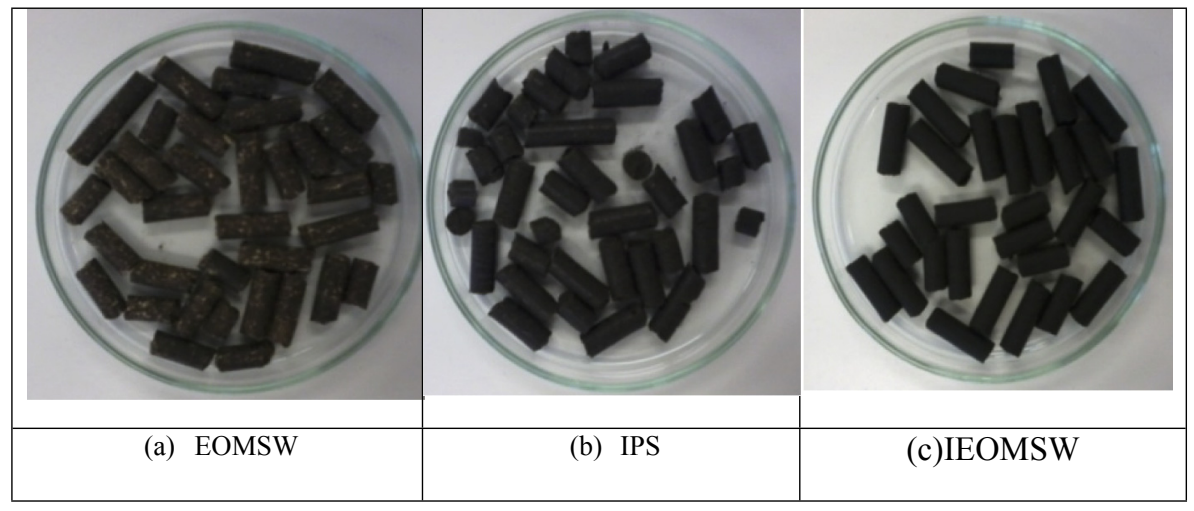

Fig. 1. Photos of the prepared pellets.

diameter, is electrically heated. Before injecting the different gases $\left(\mathrm{H}_{2} \mathrm{O}_{\mathrm{v}}\right.$ and/or $\mathrm{CO}_{2}$ and $\left.\mathrm{N}_{2}\right)$ into the reaction zones, they are preheated to the reaction temperature. The weighing system is based on electronic scale with an accuracy of $\pm 0.1 \mathrm{mg}$ and a metallic stand placed over the scale on which are placed three ceramic hollow tubes with $1 \mathrm{~m}$ length and $2.4 \mathrm{~mm}$ external diameter. These tubes hold a platinum basket of $50 \mathrm{~mm}$ diameter, a solid bottom and a side wall made from a $0.5 \mathrm{~mm}$ grid to permit the gas to pass through it. The whole weighing system can be moved in the vertical direction using a crank handle which allows introducing the sample inside the reactor hot zone within $13-15 \mathrm{~s}$. These conditions of very fast heating (near to $100^{\circ} \mathrm{C} / \mathrm{s}$ ) are similar to those encountered in fluidized bed reactors.

The fast pyrolysis phase is implemented under inert atmosphere (13 NL. min $^{-1} \mathrm{~N}_{2}$ ). At the end of the pyrolysis stage (constant mass), steam is introduced while maintaining the total flow rate at $13 \mathrm{NL}$. $\min ^{-1}$ by decreasing that of $N_{2}$. Each test was repeated three times and average values are considered for the results interpretation. Three temperatures $\left(750^{\circ} \mathrm{C}, 850^{\circ} \mathrm{C}, 950^{\circ} \mathrm{C}\right)$ and three steam molar fractions in the gas phase $(10 \%, 20 \%, 30 \%)$ were adopted for these tests. These percentages of steam in the whole mixture $\mathrm{H}_{2} \mathrm{O} / \mathrm{N}_{2}$ can be seen also as the partial pressure of the steam. In literature, gasification process occurs at lower temperatures, but with a catalytic effect $\left(<600^{\circ} \mathrm{C}\right)[24,25]$ and also, at higher temperatures (up to $1350^{\circ} \mathrm{C}$ ) than the range of temperatures considered in this study [26-28]. The choice of the present study is based on previous works $[10,11,13,23]$ realized with the same device in the same laboratory (RAPSODEE). Therefore, it is possible to compare the performances of our pellets with wood chips during gasification.

At this stade, it seems also important to identify the different regimes evolved during the pyrogasification of the prepared pellets. In fact, It is well known that the particles size [29], and the heating rate [30] are the two crucial parameters governing the pyrogasifcation process. In fact, Van de Steene et al. [31] have decreased the particle size up to a constant velocity of mass loss. They have concluded that there are no diffusionnels limitations at this state. In addition Guizani et al. [32] have performed similar investigations in order to evaluate the extent of diffusional limitations by varying the temperature and the char particle size. Authors have quantified the extent of the internal diffusional limitation for particle sizing ranging between $0.04 \mathrm{~mm}$ and $13 \mathrm{~mm}$. In this present investigation, the tested pellets are larger in terms of length $(15-30 \mathrm{~mm})$ and diameter $(5-6 \mathrm{~mm})$, whereas the experimental conditions are quite similar $750-950^{\circ} \mathrm{C}$. Therefore, we may conclude that for the same temperatures interval, the sizes of our pellets exceed the limits of the diffusional regime stated by theses authors [30,31].

\subsection{Reactivity of the agro-pellets}

From the $m(t)$ data, we can determine graphically the characteristic times of pyrolysis and gasification $\tau_{p}$ and $\tau_{G}$.

$\tau_{p}=t_{c m-p y r}-t_{\text {intro }}$

$t_{c m}$ is the time when the mass becomes constant $(d m / d t=0)$ and $t_{\text {intro }}$ is the time needed for introducing the sample inside the reactor hot zone (15 s).

Besides, $\tau_{G}$ corresponds to the time needed to reach $97 \%$ of char conversion:

$\tau_{G}=t_{X=97 \%}-t_{X=0 \%}$

Also, the pyrolysis rate $\bar{v}_{p}$ is calculated as the slope of the linear part of the mass loss curve in the pyrolysis phase.

The char gasification conversion level $\mathrm{X}$ is calculated as:

Table 1

Characteristics of the different pellets.

\begin{tabular}{|c|c|c|c|c|}
\hline Parameter & Unit & EOMSW & IEOMSW & IPS \\
\hline Moisture & (wt.\%, ar) & 10 & 15 & 10 \\
\hline Ash & (wt.\%, db) & 3.3 & 8.2 & 4.4 \\
\hline Volatile Matter & (wt.\%,db) & 68.3 & 71.2 & 76.0 \\
\hline Fixed Carbon & (wt.\%,db) & 28.4 & 20.6 & 19.6 \\
\hline Bulk density & $\left(\mathrm{kg} \cdot \mathrm{m}^{-3}\right)$ & 626 & 690 & 550 \\
\hline Unit density & $\left(\mathrm{kg} \cdot \mathrm{m}^{-3}\right)$ & 1400 & 1450 & 1170 \\
\hline porosity & & 0.55 & 0.52 & 0.53 \\
\hline $\mathrm{LHV}^{\mathrm{wb}}$ & $\left(\mathrm{MJ} . \mathrm{kg}^{-1}\right)$ & 16.3 & 19.8 & 18.5 \\
\hline $\mathrm{ED}_{\text {pellets }}$ & $\left(\mathrm{GJ} \cdot \mathrm{m}^{-3}\right)$ & 10.2 & 13.7 & 10.2 \\
\hline C & $(\%)_{\mathrm{db}}$ & 51.3 & 54.4 & 57 \\
\hline $\mathrm{H}$ & $(\%)_{\mathrm{db}}$ & 6.5 & 6.8 & 7.3 \\
\hline $\mathrm{O}$ & $(\%)$ & 41.4 & 37.0 & 34.7 \\
\hline $\mathrm{N}$ & $(\%)_{\mathrm{db}}$ & 0.8 & 1.8 & 1.0 \\
\hline$S$ & $\left(\mathrm{~g} \cdot \mathrm{kg}^{-1}\right)_{\mathrm{db}}$ & 1.99 & 2.55 & 1.55 \\
\hline K & & 3.67 & 7.53 & 3.40 \\
\hline $\mathrm{Cl}$ & & 3.44 & 6.28 & 6.12 \\
\hline $\mathrm{Na}$ & & 0.78 & 1.79 & 1.15 \\
\hline $\mathrm{Ca}$ & & 1.13 & 1.45 & 0.87 \\
\hline $\mathrm{Si}$ & & 0.09 & 0.21 & 0.16 \\
\hline $\mathrm{P}$ & & 0.13 & 0.23 & 0.18 \\
\hline $\mathrm{Mg}$ & & 0.12 & 0.22 & 0.16 \\
\hline $\mathrm{Fe}$ & & 0.04 & 1.00 & 0.90 \\
\hline $\mathrm{K}+\mathrm{Na}+\mathrm{S}+\mathrm{Cl}$ & & 9.88 & 18.15 & 12.22 \\
\hline$(\mathrm{K}+\mathrm{Na}) /(2 \mathrm{~S}+\mathrm{Cl})$ & $\mathrm{mol} / \mathrm{mol}$ & 0.58 & 0.80 & 0.51 \\
\hline$(\mathrm{Si}+\mathrm{P}+\mathrm{K}) /(\mathrm{Ca}+\mathrm{Mg})$ & $\mathrm{mol} / \mathrm{mol}$ & 3.06 & 4.59 & 3.48 \\
\hline
\end{tabular}

db: dry basis, ar: as received. 


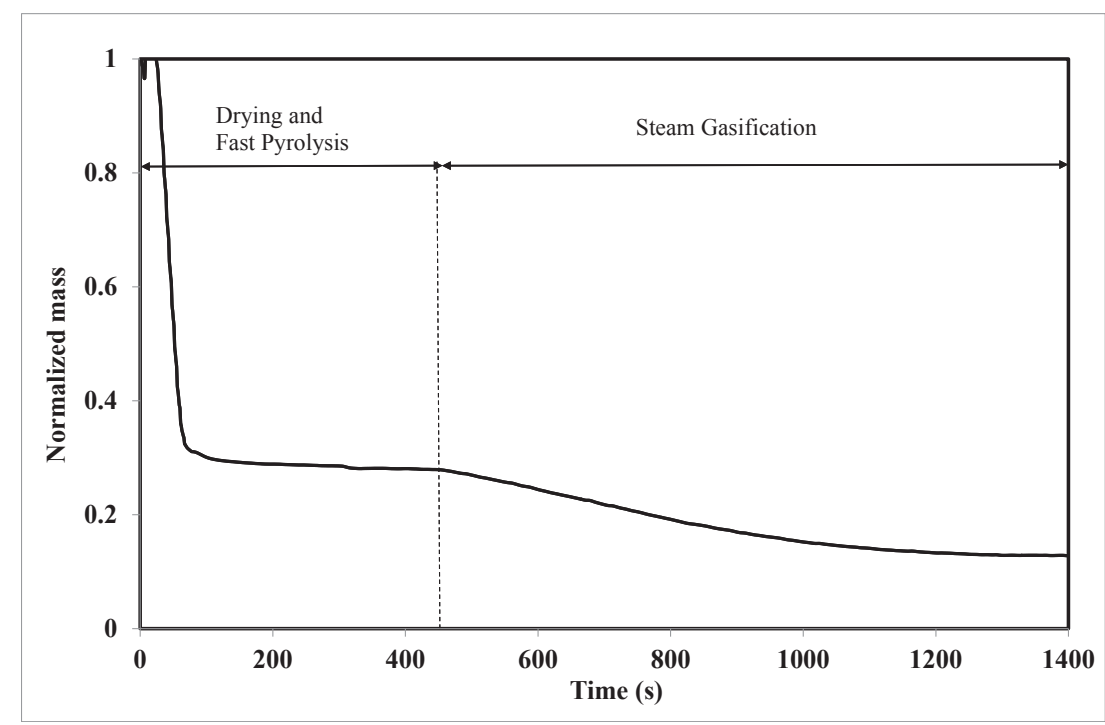

Fig. 2. Typical result for normalized mass evolution with time during the pellets pyro-gasification.

Table 2

Times and rates characteristics during pyro-gasification of the different samples, under $850{ }^{\circ} \mathrm{C}$ and $20 \% \mathrm{H}_{2} \mathrm{O}$ vapor conditions.

\begin{tabular}{|c|c|c|c|c|c|c|c|}
\hline \multicolumn{5}{|c|}{ Fast pyrolysis phase } & \multirow[b]{2}{*}{ EOMSW } & \multicolumn{2}{|c|}{ Gasification phase } \\
\hline & EOMSW & IEOMSW & IPS & & & IEOMSW & IPS \\
\hline$\tau_{p}(s)$ & $114 \pm 2$ & $154 \pm 2$ & $104 \pm 2$ & $\tau_{G}(s)$ & $830 \pm 5$ & $755 \pm 5$ & $666 \pm 6$ \\
\hline $\bar{v}_{p}\left(10^{-3} s^{-1}\right)$ & $8.85 \pm 0.35$ & $6.49 \pm 0.32$ & $11.1 \pm 0.4$ & $\bar{v}_{g}\left(10^{-3} s^{-1}\right)$ & $1.21 \pm 0.02$ & $1.33 \pm 0.03$ & $1.50 \pm 0.02$ \\
\hline
\end{tabular}

$X(t)=\frac{m_{i}-m_{t}}{m_{i}-m_{f}}$

where, $m_{i}$ is the initial mass of the char, $m_{t}$ is the mass at $\mathrm{t}$ and $m_{f}$ is the final mass.

The gasification rate is calculated as follows:

$v_{g}(t)=\frac{d X}{d t}(\mathrm{t})$

$\bar{v}_{g}$ is the mean gasification rate calculated as the average value of the conversion rate throughout the char conversion range.

\section{Results and discussions}

\subsection{Pellets characteristics}

Photos of the prepared pellets are shown in Fig. 1. The main properties of the different pellets are presented in Table 1. The ultimate analysis was performed using the CHONS analyser, whereas the minerals were analysed using the ICP-AES technique.

A higher variability is observed in the properties of the different prepared pellets. In particular, the low heating value varies from $16.3 \mathrm{MJ} \mathrm{kg}^{-1}$ for EOMSW to $19.8 \mathrm{MJ} \mathrm{kg}^{-1}$ for IEOMSW. The ash content varies from $3 \mathrm{wt} \%$ for EOMSW pellets to $7 \mathrm{wt} \%$ for the IEOMSW pellets. The nitrogen content varies from $0.8 \mathrm{wt} \%$ for EOMSW to $1.8 \mathrm{wt} \%$ for IEOMSW. The nitrogen is highly presented initially in the agrifood industry residues such as [19-21].

The analysis of the inorganic elements shows that, as expected, $\mathrm{K}$ and $\mathrm{Cl}$ are the major elements present in the different agropellets. These elements, as well as the presence of $\mathrm{Na}$ and $\mathrm{Ca}$ are mainly due to the use of brackish water during the olive oil extraction process.
In addition, $\mathrm{P}, \mathrm{Fe}, \mathrm{Mg}$ and $\mathrm{Si}$ are also present, but at lower concentrations.

\subsection{Pellets gasification reactivity}

Fig. 2 shows a typical result of pyro-gasification process. The normalized mass profile can be divided after the drying step in two main stages. Every time about $2 \mathrm{~g}$ of the pellet were used during each gasification test.

The first one corresponds to the fast pyrolysis stage (on the left). During this stage, the major biomass components namely hemicellulose, cellulose and lignin are rapidly degraded. The thermal decomposition of these compounds lead to the emission of various gaseous products including $\mathrm{CO}, \mathrm{CO}_{2}$ and hydrocarbons $\mathrm{C}_{\mathrm{n}} \mathrm{H}_{\mathrm{m}}$ (in

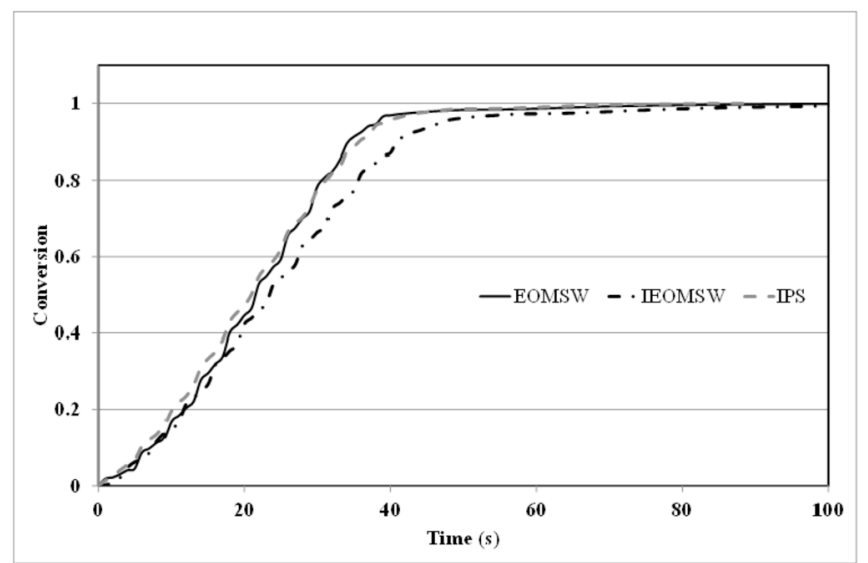

Fig. 3. Comparison of the conversion during fast pyrolysis of the three pellets. 


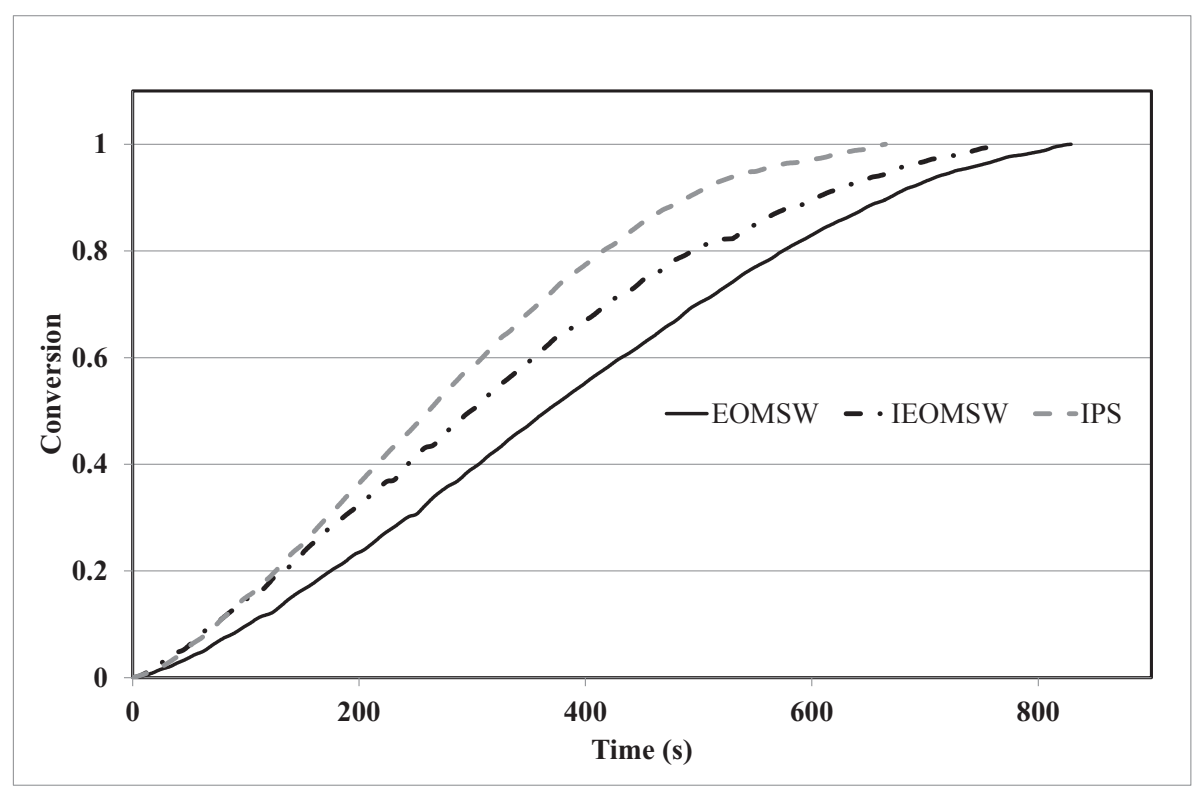

Fig. 4. Comparison of the conversion during gasification of the three pellets under $20 \% \mathrm{H}_{2} \mathrm{O} / 80 \% \mathrm{~N}_{2}$ at $850{ }^{\circ} \mathrm{C}$.

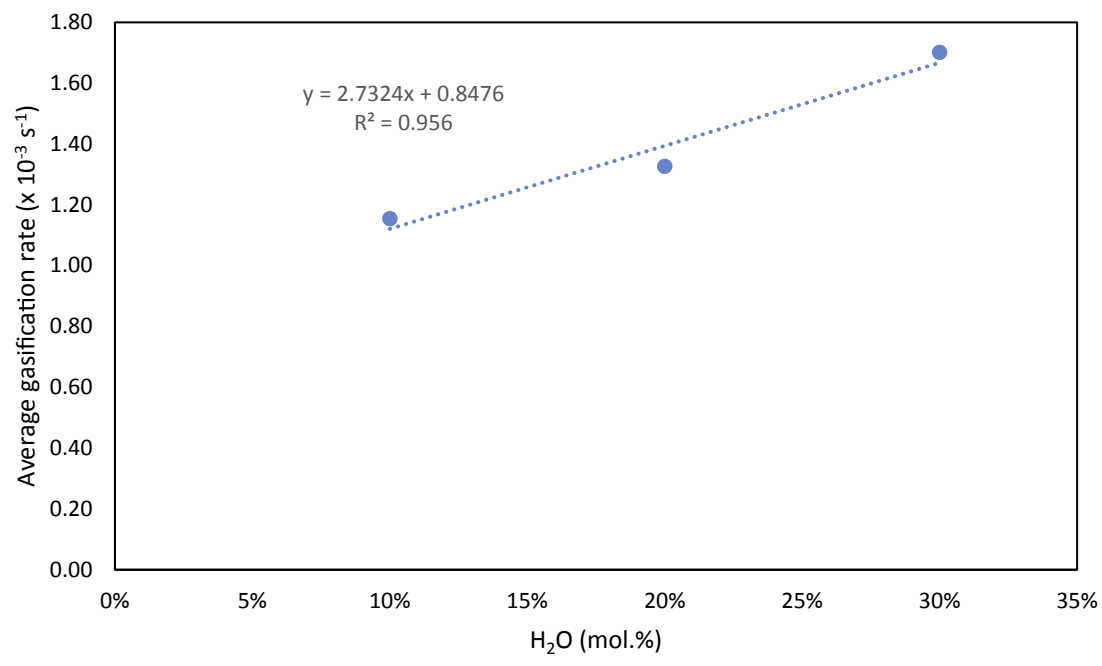

Fig. 5. Evolution of the mean gasification rate of IEOMSW as a function of the steam concentrations.

which $\mathrm{CH}_{4}$ is the major gas). Furthermore, a certain percentage of TARs and char are formed during the fast pyrolysis stage. TARs are composed mainly by condensable organic compounds which vary from primary oxygenated components to more heavily deoxygenated hydrocarbons and polycyclic aromatic hydrocarbons (PAHs) [33]. The fraction of the gaseous and solid products depends strongly from the operating conditions. However, it is well known that fast pyrolysis and temperature above $800^{\circ} \mathrm{C}$ favor the formation of gaseous products $[34,35]$.

The second stage shown in Fig. 2 (on the right) corresponds to the char gasification under steam which reacts with the char to produce mainly $\mathrm{H}_{2}, \mathrm{CO}$ and $\mathrm{CO}_{2}$. The char gasification stage is by far the rate limiting step.

\subsubsection{Effect of the pellets properties on the pyro-gasification} reactivity

The pyro-gasification of the prepared pellets, i. e EOMSW, IEOMSW and IPS was examined at $850{ }^{\circ} \mathrm{C}$ under $20 \% \mathrm{H}_{2} \mathrm{O} / 80 \% \mathrm{~N}_{2}$ with a flow rate of $13 \mathrm{NL}$. $\min ^{-1}$. Table 2 shows the main characteristics extracted from $m(t)$ data.

In Table 2 are consigned the characteristic times and mean rates in the pyrolysis and gasification stages for the 3 pellets. In addition, Figs. 3 and 4 show the conversion level versus time during the fast pyrolysis and the gasification step of the three prepared pellets, respectively.

During the fast pyrolysis step, the results indicate that the highest pyrolysis time (154 s) is obtained for IEOMSW, while it is comparable for the two other pellets (104 and $114 \mathrm{~s}$ ). Such behavior may be attributed to the presence of organic compounds in the IEOMSW such as polyphenols [19-22]. The char yields were comparable for the three pellets (17-18\%). These char yields were slightly lower than the ones obtained in previous investigation under slow pyrolysis conditions (20-25\%) [20].

During the gasification step, the EOMSW shows the lowest gasification reactivity. The characteristic time of gasification shown in Table 2 is $830 \mathrm{~s}$. The impregnated samples exhibited lower 


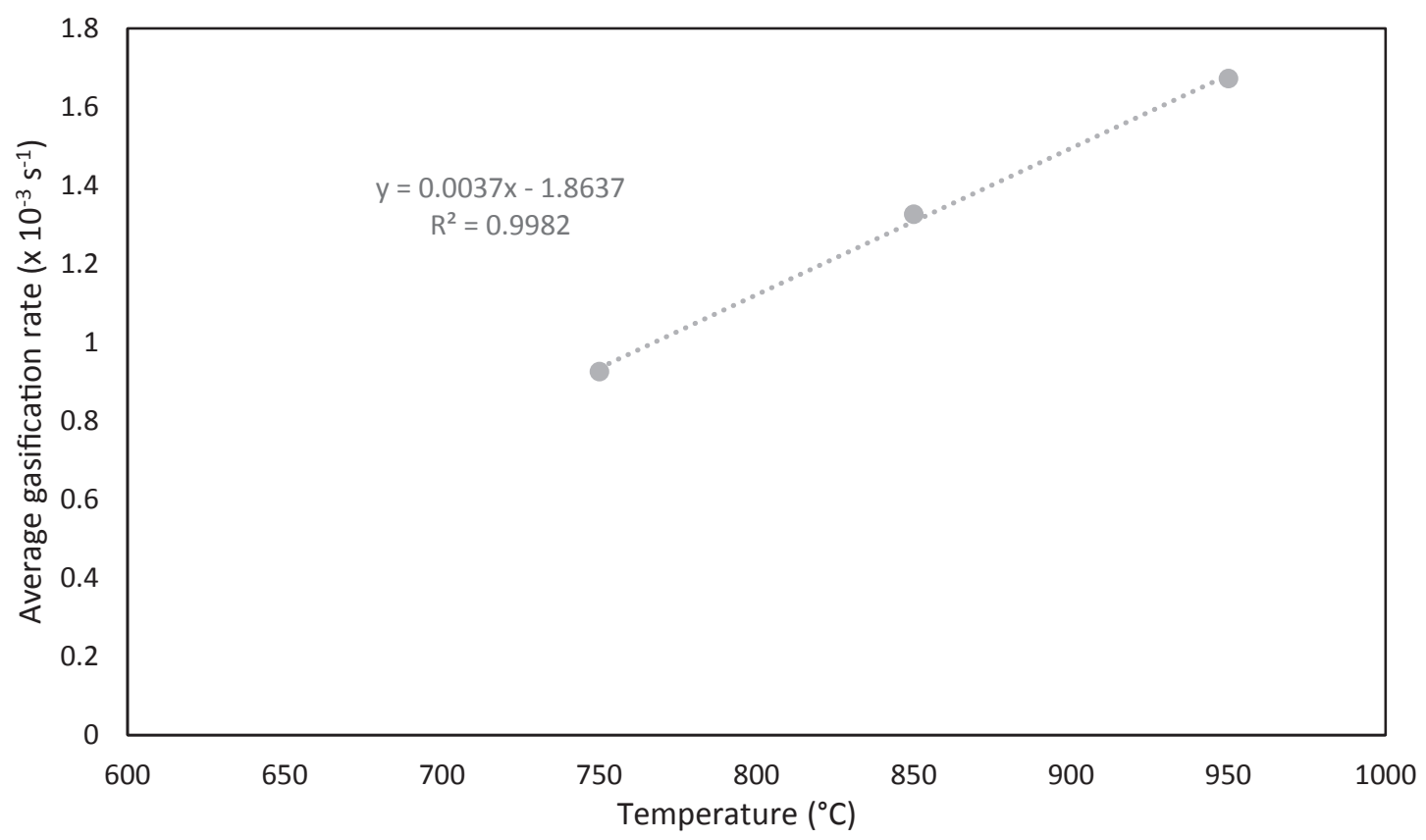

Fig. 6. Evolution of the mean gasification rate of IEOMSW as a function of the temperature.

Table 3

Effect of Temperature and $\mathrm{H}_{2} \mathrm{O}$ vapor concentration during IEOMSW gasification.

\begin{tabular}{lllll}
\hline & $750{ }^{\circ} \mathrm{C}, 20 \% \mathrm{H}_{2} \mathrm{O}$ & $850{ }^{\circ} \mathrm{C}, 10 \% \mathrm{H}_{2} \mathrm{O}$ & $850{ }^{\circ} \mathrm{C}, 20 \% \mathrm{H}_{2} \mathrm{O}$ & $850{ }^{\circ} \mathrm{C}, 30 \% \mathrm{H}_{2} \mathrm{O}$ \\
\hline$\tau_{p}(s)$ & $168 \pm 2$ & $154 \pm 2$ & & \\
$\bar{v}_{p}\left(10^{-3} s^{-1}\right)$ & $5.91 \pm 0.25$ & $6.49 \pm 0.32$ & & \\
Char Yield (\%) & $17.3 \pm 0.2$ & $16.6 \pm 0.2$ & & \\
$\tau_{G}(s)$ & $1080 \pm 5$ & $866 \pm 5$ & $755 \pm 5$ & $1.2 \pm 0.4$ \\
$v_{G}\left(10^{-3} s^{-1}\right)$ & $0.93 \pm 0.02$ & $1.15 \pm 0.02$ & $1.33 \pm 0.03$ & $588 \pm 5$ \\
\hline
\end{tabular}

gasification times (755 s for IEOMSW and 660 for IPS). Such behavior may be attributed to the catalytic effect of minerals provided by OMWW after the impregnation process. The role of mineral contents on the gasification of biomass char is well identified in the literature [13], especially for the K element which is has a high catalytic effect $[17,18,36]$ and it is the major mineral component as it is shown in Table 1.

Similar investigations were performed by Guizani et al. [37] for beech wood chips in the same experimental device. Authors obtained a gasification time $\tau_{G}(\approx 680 \mathrm{~s})$ which is very close for the gasification time of impregnated pine sawdust, IPS (660 s). These results indicate that the impregnation of OMWW followed by the gasification of the impregnated samples could be a strategy for the valorization of OMWW. In the following section, we investigated further the gasification potential of the IEOMSW pellets. This choice is motivated by the recovery of both olive oil mill residues for a circular economy approach.

\subsubsection{Effect of temperature and steam concentration on the} IEOMSW pellets pyro-gasification

In order to study the influence of the temperature, the pyrogasification of IEOMSW pellets was examined at three temperatures of $750^{\circ} \mathrm{C}, 850^{\circ} \mathrm{C}$ and $950^{\circ} \mathrm{C}$ with a steam molar fraction of $20 \%$. The effect of steam partial pressures of $10 \%, 20 \%$ and $30 \%$ was investigated at $850^{\circ} \mathrm{C}$. Table 3 shows the gasification times and rates for different temperatures and steam fractions.

The pyrolysis characteristic times of the IEOMSW were respectively $168 \mathrm{~s}, 154 \mathrm{~s}$ and $88 \mathrm{~s}$ respectively at $750^{\circ} \mathrm{C}, 850^{\circ} \mathrm{C}$ and $950^{\circ} \mathrm{C}$.
The char yield did not vary too much in this temperature interval and was in the range of (16.5-17.6\%). The decrease of the pyrolysis characteristic time with temperature was also accompanied by a decrease of the char gasification characteristic time which was estimated respectively at $1080 \mathrm{~s}, 755 \mathrm{~s}$ and $598 \mathrm{~s}$ at $750^{\circ} \mathrm{C}, 850^{\circ} \mathrm{C}$ and $950^{\circ} \mathrm{C}$. The char gasification is hence the rate limiting step in the whole pellets pyro-gasification reaction. Recently, Guizani et al. [37] analyzed gasification of beech wood particles under steam, carbon dioxide and their mixture. They found that the char reactivity for $\mathrm{T}=900{ }^{\circ} \mathrm{C}$ and under $20 \% \mathrm{H}_{2} \mathrm{O}$ increased from $0.004 \mathrm{~s}^{-1}$ for conversion ratio $X=10 \%$ to about $0.015 \mathrm{~s}^{-1}$ for $X=90 \%$. These values are higher than the mean value obtained for IEOMSW under the same conditions $\left(1.6710^{-3} \mathrm{~s}\right)$. This difference may be attributed to the diffusional limitations during the pellets gasification.

The high heating rate char gasification presents similar conditions to fluidized bed gasification. Indeed, the biomass particles are submitted to a thermal shock in the macro-TG exactly to that endured when they are feeding a fluidized bed. In addition, it was be found that the reaction rate in a mixture of $\mathrm{H}_{2} \mathrm{O}$ and/or $\mathrm{CO}_{2}$ is nearly well represented by the sum of the individual reaction rates [37,38]. In the same context, Nilsson et al. [39] focused on the gasification study of char prepared from olive tree pruning in a fluidized bed heated between 760 and $900^{\circ} \mathrm{C}$. The gasifier atmosphere was composed by a mixture of $\mathrm{H}_{2} \mathrm{O}, \mathrm{CO}_{2}, \mathrm{H}_{2}, \mathrm{CO}$ and $\mathrm{N}_{2}$. By performing a detailed kinetic study authors succeed to show the inhibition character of $\mathrm{H}_{2}$ and $\mathrm{CO}$, and conclude that the conversion rate with $\mathrm{H}_{2} \mathrm{O}$ was to be $3-4$ times faster than that with $\mathrm{CO}_{2}$. For a conversion level $\mathrm{X}=0.2$, a temperature of $840^{\circ} \mathrm{C}$ and a partial 
pressure of steam $=0.20$, authors obtained a conversion rate equal to $3.510^{-3} \mathrm{~s}$. This value is about 2 times higher than the value we obtained with IEOMSW in similar conditions. The discrepancy may come from the difference of the biomasses in their textural compositions.

The effects of steam fraction and temperature on the mean gasification rate are illustrated in Figs. 5 and 6, respectively.

One can notice that the average gasification rate evolves linearly with these two parameters as it increases from $0.9310^{-3} \mathrm{~s}^{-1}$ to $0.16710^{-3} \mathrm{~s}^{-1}$ when increasing the temperature from $750{ }^{\circ} \mathrm{C}$ to $950{ }^{\circ} \mathrm{C}$, and from $1.1510^{-3} \mathrm{~s}^{-1}$ to $1.7210^{-3} \mathrm{~s}^{-1}$ when the partial pressure of steam was increased from 10 to $30 \%$. These values are in the same order of magnitude as those found in literature. In particular, Fisher et al. [40] obtained a reactivity of $1.210^{-3} \mathrm{~s}^{-1}$ during the gasification of willow under $27 \pm 4 \mathrm{vol} \% \mathrm{H}_{2} \mathrm{O}$ at $850^{\circ} \mathrm{C}$ which is very close to the reactivity of IEOMSW under $20 \% \mathrm{H}_{2} \mathrm{O}$ at $850^{\circ} \mathrm{C}$ (Table 3). Furthermore, Nilsson et al. [38,39] showed during their investigations that the reaction rate increased linearly as function of the temperature for different gasifiers and for different ratios.

These different trends give a general idea on the gasification potential of such agro-waste pellets prepared from olive mill wastes. This valorization route transforms those wastes into syngas and eliminates many problems related to their random the disposal in environmental spaces these wastes. In next works, investigations concerning the quantitative gaseous analysis during gasification and the effect of catalysts such as potassium as well as a kinetic study will be taken into account.

\section{Conclusion}

The pyro-gasification potential of three types of formulated agro-pellets comprising olive mill waste biomass was investigated via Macro-thermogravimetric.

The behavior of the pellets composed of exhausted olive mill solid waste (EOMSW), and impregnated ones: IPS (pine sawdust/ olive mill wastewater) and IEOMSW (EOMSW/olive mill wastewater), during the fast pyrolysis and char gasification stages were generally comparable despite some small differences in the conversion rates or char yields.

The pyro-gasification potential of the formulated IEOMSW pellets was investigated further as a route for the valorization of these wastes and reduction of their pollution impacts. The pellets pyrolysis rate was affected significantly by the temperature in the range of $750^{\circ} \mathrm{C}-950^{\circ} \mathrm{C}$. The mean char gasification rate was linearly dependent on temperature and steam molar fractions in the respective ranges of $750^{\circ} \mathrm{C}-950^{\circ} \mathrm{C}$ and $10 \%-30 \%$ of steam. These practical data on the fast pyrolysis and char gasification potential of IEOMSW can be used for the design and operation of gasifiers operating with those kind of wastes. Further investigations are needed especially concerning the gas analysis to have a wider view on the use of these wastes as fuels in biomass gasifiers.

\section{Acknowledgment}

Marzouk Lajili would like to thank Professor Ange Nzihou the director of the RAPSODEE Centre (Mines Albi in France) and all members of UMR5302 and especially, Professor Sylvain Salvador. Also, Marzouk Lajili is grateful to the IFT (Institute of FranceTunisia) for supporting financially this work.

\section{References}

[1] Squalli J. Renewable energy, coal as a baseload power source, and greenhouse gas emissions: evidence from U.S. state-level data. Energy 2017;127:479-88.
[2] Neri E, Cespi D, Setti L, Gombi E, Bernardi E, Vassura I, et al. Biomass residues to renewable energy: a life cycle perspective applied at a local scale. Energies 2016:9(11):895.

[3] Guizani C, Haddad K, Jeguirim M, Colin B, Limousy L. Combustion characteristics and kinetics of torrefied olive pomace. Energy 2016;107:453-63.

[4] Kraiem N, Lajili M, Limousy L, Said R, Jeguirim M. Energy recovery from Tunisian agri-food wastes: evaluation of combustion performance and emissions characteristics of green pellets prepared from tomato residues and grape marc. Energy 2016;107:409-18.

[5] Haddad K, Jeguirim M, Jellali S, Delmotte L, Bennici S, Limousy L. Combined NMR structural characterization and thermogravimetric analyses for the assessment of the AAEM effect during lignocellulosic biomass pyrolysis. Energy $2017 ; 134: 10-23$

[6] Tamošiūnas A, Chouchène A, Valatkevičius P, Gimžauskaite D, Aikas M, Uscila $\mathrm{R}$, et al. The potential of thermal plasma gasification of olive pomace charcoal. Energies 2017;10(5):710.

[7] García Fernández R, Pizarro García C, Gutiérrez Lavín A, Bueno de las Heras JL. Study of main combustion characteristics for biomass fuels used in boilers. Fuel Process Technol 2012;103:16-26.

[8] Scala F, Chirone R. An SEM/EDX study of bed agglomerates formed during fluidized bed combustion of three biomass fuels. Biomass \& Bioenergy 2008:32:252-66.

[9] D'Orazio A, Rapagn S, Foscolo PU, Gallucci K, Nacken M, Heidenreich S, et al. Gas conditioning in $\mathrm{H} 2$ rich syngas production by biomass steam gasification: experimental comparison between three innovative ceramic filter candles. Int J Hydrogen Energy 2015;40:7282-90.

[10] Guizani C, Jeguirim M, Gadiou R, Escudero Sanz FJ, Salvador S. Biomass char gasification by $\mathrm{H}_{2} \mathrm{O}, \mathrm{CO}_{2}$ and their mixture: evolution of chemical, textural and structural properties of the chars. Energy 2016;112:133-45.

[11] Nzihou A, Stanmore B, Sharrock P. A review of catalysts for the gasification of biomass char, with some reference to coal. Energy 2013:58:305-17.

[12] Snehesh AS, Mukunda HS, Mahapatra S, Dasappa S. Fischer-Tropsch route for the conversion of biomass to liquid fuels - technical and economic analysis. Energy 2017;130:182-91.

[13] Hognon C, Dupont C, Grateau M, Delrue F. Comparison of steam gasification reactivity of algal and lignocellulosic biomass: influence of inorganic elements. Bioresour Technol 2014;164:347-53.

[14] Prabowo B, Umeki K, Yan M, Nakamura MR, Castaldi MJ, Yoshikawa K. $\mathrm{CO}_{2}$ steam mixture for direct and indirect gasification of rice straw in a downdraft gasifier: laboratory-scale experiments and performance prediction. Appl energy 2014;113:670-9.

[15] Kirubakaran V, Sivaramakrishnan V, Nalinic R, Sekar T, Premalatha M, Subramanian P. A review on gasification of biomass. Renew Sustain Energy Rev 2009;13:179-86.

[16] Prins MJ, Ptasinski KJ, Janssen FJJG. Thermodynamics of gas-char reactions: first and second low analysis. Chem Eng Sci 2003;58:1003-11.

[17] Bouraoui Z, Jeguirim M, Guizani C, Limousy L, Dupont C, Gadiou R. Thermogravimetric study on the influence of structural, textural and chemical properties of biomass chars on CO2 gasification reactivity. Energy 2015;88: $703-10$.

[18] Bouraoui Z, Dupont C, Jeguirim M, Limousy L, Gadiou R. CO2 gasification of woody biomass chars: the influence of $\mathrm{K}$ and $\mathrm{Si}$ on char reactivity. Comptes Rendus Chim 2016;19:457-65.

[19] Jeguirim M, Chouchene A, Trouvé G, Favre-Reguillon A, Le Buzit G. A new valorisation strategy of olive mill wastewater: impregnation on sawdust and combustion. Resour Conservat Recycl 2012;59:4-8.

[20] Kraiem N, Jeguirim M, Limousy L, Lajili M, Dorge S, Michelin L, et al. Impregnation of olive mill wastewater on dry biomasses: impact on chemical properties and combustion performances. Energy 2014;78:479-89.

[21] Lajili M, Limousy L, Jeguirim M. Physico-Chemical properties and thermal degradation characteristics of agropellets from olive mill by-products/ sawdust blends. Fuel Process Technol 2014;126:215-21.

[22] Lajili M, Jeguirim M, Kraiem N, Limousy L. Performance of a household boiler fed with agropellets blended from olive mill solid waste and pine sawdust. Fuel 2015;153:431-6.

[23] Guizani C. Effect of $\mathrm{CO} 2$ on the biomass pyro-gasification in high heating rate and low heating rate conditions [PhD thesis]. Ecole des Mines d'Albi; 2014.

[24] Liuyun L, Kayoko M, Haruto M, Kunihiko Y, Takayuki T. Low-temperature gasification of a woody biomass under a nickel-loaded brown coal char. Fuel Process Technol 2010;91:889-94.

[25] Ravaghi-Ardebeli Z, Manenti F, Corbetta M, Pirola C. Biomass gasification using low-temperature solar-driven steam supply. Renew Energy 2015;74: $671-80$.

[26] Umeki K, Yamamoto K, Namioka T, Yochikawa K. High temperature steamonly gasification of woody biomass. Appl energy 2010;87:791-8.

[27] Zhou J, Chen Q, Zhao H, Cao X, Mei Q, Luo Z, et al. Biomass-oxygen gasification in a high-temperature entrained-flow gasifier. Biotechnol Adv 2009;27: 606-11.

[28] Qin K, Lin W, Jensen PA, Jensen AD. High temperature entrained flow gasification of biomass. Fuel 2012;93:589-600.

[29] Septien S, Valin S, Dupont C, Peyrot M, Salvador S. Effect of particle size and temperature on woody biomass fast pyrolysis at high temperature $\left(1000-1400^{\circ} \mathrm{C}\right)$. Fuel 2012;97:202-10.

[30] Mehrabian R, Scharler R, Obernberger I. Effect of pyrolysis conditions on the heating rate in biomass particles and applicability of TGA kinetic parameters 
in particle thermal conversion modeling. Fuel 2012;93:567-75.

[31] Van de Steene L, Tagutchou JP, Escudero Sanz FJ, Salvador S. Gasification of woodchip particles: experimental and numerical study of char- $\mathrm{H}_{2} \mathrm{O}$, char- $\mathrm{CO}_{2}$ and char- $\mathrm{O}_{2}$ reactions. Chem Eng Sci 2011;66:4499-509.

[32] Guizani C, Escudero Sanz FJ, Salvador S. Influence of temperature and particle size on the single and mixed atmosphere gasification of biomass char with $\mathrm{H}_{2} \mathrm{O}$ and $\mathrm{CO}_{2}$. Fuel Process Technol 2015;134:175-88.

[33] López-González D, Fernandez-Lopez M, Valverde JL, Sanchez-Silva L. Gasification of lignocellulosic biomass char obtained from pyrolysis: kinetic and evolved gas analyses. Energy 2014;71:456-67.

[34] Guizani C, Escudero Sanz FJ, Salvador S. Effect of $\mathrm{CO}_{2}$ on biomass fast pyrolysis: reaction rate, gas yields and char reactive properties. fuel 2014;116: 310-20.

[35] Fisher EM, Dupont C, Darvell LI, Commandré JM, Saddawi A, Jones JM, et al. Combustion and gasification characteristics of chars from raw and torrefied biomass. Bioresour Technol 2012;119:157-65.
[36] Jeguirim M, Kraeim N, Lajili M, Guizani C, Zopras A, Leva Y, et al. The relationship between mineral contents, particle matter and bottom ash distribution during pellet combustion: molar balance and chemometric analysis. Environ Sci Pollut Res 2017;24:9927-39.

[37] Guizani C, Escudero Sanz FJ, Salvador S. The gasification reactivity of highheating-rate chars in single and mixed atmospheres of $\mathrm{H}_{2} \mathrm{O}$ and $\mathrm{CO}_{2}$. Fuel 2013;108:812-23.

[38] Nilsson S, Gómez-Barea A, Ollero P. Gasification of char from dried sewage sludge in fluidized bed: reaction rate in mixtures of $\mathrm{CO}_{2}$ and $\mathrm{H}_{2} \mathrm{O}$. Fuel 2013;105:764-8.

[39] Nilsson S, Gómez-Barea A, Fuentes-Cano D, Campoy M. Gasification kinetics of char from olive tree pruning in fluidized bed. Fuel 2014;125:192-9.

[40] Fisher EM, Dupont C, Darvell LI, Commandré JM, Saddawi A, Jones JM, et al. Combustion and gasification characteristics of chars from raw and torrefied biomass. Bioresour Technol 2012;119:157-65. 